\title{
Implication of Educational Technology on Quality Teaching: Appraisal from the Perspective of Secondary Schools in the South West Region of Cameroon
}

\author{
Mbah Emmanuel Teke \\ Department of Curriculum Studies and Teaching, Faculty of Education, University of Buea, Cameroon
}

\begin{abstract}
The purpose of this research paper was to find out the implications of educational technology on quality teaching in secondary schools in the South West Region of Cameroon. The study had just one objective and was carried out in six divisions in the south west region. The survey research design was used and the sample was selected using the simple random sampling and the appropriate stratified random sampling technique. The sample consisted of 330 students and 100 teachers.
\end{abstract}

The questionnaire and the interview were instruments used in the study to collect data. The descriptive statistics comprised tables, percentages, bars and pie charts while for inferential statistics, chi square test of independence was used to verify hypothesis. The results show that the null hypothesis was rejected and the alternative retained.

Some recommendations were made to better the use of ICTs in the teaching and learning process to both teachers and students

KEYWORDS: Implication, Education, Technology, Quality, Teaching, Appraisal, Perspective, System

\section{INTRODUCTION}

Educational technology is most simply and comfortably defined as an era of tools that have proven helpful in advancing students learning. Educational technology relies on a broad definition of the word technology. Technology can refer to material objects of use to humanity such as machines or hardware, but it can encompass broader themes, including systems, methods of organization and techniques. BednarMr\&Suceeder (2005). Richey R.C (2008) states that technology of modern times is not limited to projectors, laptop computers and calculators. New tools such as smart phones and games cartoons are beginning to draw serious attention.

In this light, to be effective when using technology, teachers need to be highly involved by interacting and employing diverse technological appliances and applications. Researchers indicate that approximate technology use can be very beneficial to increase educational productivity (Byrom and Brigham 2001), Clements and Sarama 2003.

Technology enables teachers with well-developed working theories of the student learning to extend the reach and power of these theories; in the absence of these theories technology enables mediocrity.

Educational technology is involved in the facilitating of human learning through the systematic identification, development, organization and utilization of a full range of learning resources. Educational technology is also called learning technology.

Tambo (2002) has observed that Cameroonian schools and classrooms are often bear of teaching mediums. This makes leaning extremely difficult for students because they often have no other media like film, computer program, model audiotape, television projectors etc.
Consequently, educational technology has awakened the attention of many educators the world over. Its effect on the teaching learning process has been the priority of the research.

\section{PROBLEM STATEMENT}

The need for self-directed learning in secondary schools in the South West Region cannot be over emphasized. In the traditional classroom, the learning environment includes only the teacher and the student. Students learn to depend solely on teachers for their success. That is teachers present information to the students, practice and application then occurs after instruction.

A fundamental limitation here is that students have little or no opportunities to conduct and manage their learning activities. However, technology has allowed learning to become a major dynamic process. Without doubt, there is an urgent need for the re-examination of public secondary schools capacity to create a more learner- centered environment for quality teaching and learning.

Teachers on the other hand do not have necessary training and even when they have are not motivated to make use of educational technology which can help the students learn better. This situation has for over the years been neglected since according to some educational sources "the schools are doing well anyway" (Biggs 2002). If one looks deeply into this situation, it would not be too wrong for one to add that our schools are soon developing the adage of "let sleeping dogs lie". This may sound pitiful, yet there is a constant cry for the falling standards of our educational system.

At the higher levels, the government complains of lack of resources to fully equip the schools which are over growing in number. And at the implementation end, teachers 
complain of lack of time and resources to make use of educational system.

\section{Purpose of the Study}

The purpose of the study is to examine the relationship between educational technology and quality teaching.

\section{Research Question}

Is there a relationship between educational technology and Quality teaching?

\section{BACKGROUND}

According to Tambo (2002) educational technology is concerned with the involvement of Medias which facilitates learning. He further outlined a list of these medium viz, radio, television, audio tapes, videotapes, computers, films etc. Jossey-Bass comments that 'the number and range of new technologies are increasing at a fast paste'. It is apparent that these advances can help us work more quickly and more efficiently than ever before.

However, the potential in these new Forms of Media lies not just in their speed but in their ability to completely alter the way we think, learn, remember and communicate information.

To Santrock (2004), technology brings with it certain social issues, for example, with schools increased use in technology especially computers widen the learning gap between rich and poor students or between male and female students.

Technology will and has always been part of classroom teaching and learning process. In view of the frequent changing nature of classrooms today, every technological development be it computers, internet, iPods, note-books, laptops, projectors, tapes audio and video CD's or the television, whatever they might be can be utilized to facilitate teaching and learning.

Information and communication technology (ICT) are simple technologies arising from scientific and technological progress in computer sciences, electronics and telecommunication. They enable us to process, store, retrieve and disseminate valuable information in text, sounds and video from.

In an increasing interconnected world, brought about by the application of technological advances to all sectors of society, quality education necessitates active and innovative exploration to maximize the benefits of ICTs and develop and maintain the partnership that uses ICTs in education requires.

This calls for conceptualizing and restructuring the educational enterprise, so as to confront the technological challenges of the millennium.

Despite the fact that Cameroon and other African countries are in the initial stage of introducing ICT in schools, there are documented experience on the continent on which we draw as we move forward.

Milner (1997) developed the evolutionary model understanding the integration of computers into education. The model included five phases; Introduction, entry, intermediate, penultimate and creation. She found out that schools selected for in depth study was at the entry phase in 1996.

The researchers used Milner five phase model of technology integration in school and found out that, over three years some schools had move to the penultimate phase in which there were 'changes in instructional strategies' Cossa and Cronjé, (2004). Such as gradual change of teachers role from facilitator to the collaborator improves learning on the side of the student.

In 1995, when educational experts met in Yaoundé to discuss how educational system could be improved upon, nothing was mentioned about the use of information and communication technology (ICT) in schools and classroom.

The Cameroon educational law 9/004 of 14th April 1998 does not make mention of ICT in the school system. Today teachers training colleges are now making provision for teaching ICTs and it uses for pedagogic purposes. This implies that until recently, the teaching core in Cameroon has to a great extent been computer illiterate.

In February 2001, the president of Cameroon in his message to the youths, called for embracing the knowledge economy (Republique du Cameroun, 2007c:3). In preparation, he promised the introduction of computing in schools and the endowment of computer rooms to schools.

The impact of the presidential speech accelerated in 2002, with the introduction of ICTs in government secondary and technical schools. Numerous schools have benefitted from presidential gift of multimedia centers connected to internet. Official programs of ICT were designed for secondary schools in 2003 (ERNWACA-Cameroon, 2005:11). The ministry of Education recently developed a strategy for the implication of the national ICTs policy in basic education over the years 2007-2015.

In the Cameroonian context, educational technology engages a whole range of issues. Technologies or mediums which foster learning and those which make the teaching exercise easy and straight to the objective. But it has been identified by researchers that Cameroonian classrooms are always bare of the necessary teaching medium that can facilitate learning.

In many cases, one will find teachers rushing through with complicated concepts, expecting students to understand because of lack of these technologies, learning and even teaching becomes extremely difficult. In addition, due to the abject poverty under which the average Cameroonian lives, there is a shortage of exercise and text books. Averagely one will find just about five texts books in a class of eighty students. This is often in a subject on whom much emphasis is made like English Language, Mathematics and French.

Other subjects like Biology, History , Economics, Chemistry and Physics basically do not exist in our classes today talk less of films , computer-programs, models, CD's and the internet which have the ability to turn our learning and teaching to further levels.

However, schools in Cameroon are characterized by the presence of a chalkboard, commonly referred to as the blackboard on account of the fact that most chalkboards are 
colored black. That notwithstanding, recently, some schools have been making considerable progress to improve on the use of affordable technologies to facilitate learning. Some schools mostly mission secondary schools lay emphasis on students getting all of their text books as to the subject they offer. Some few schools do make use of magnetic boards.

Schools in Cameroon also make a timid use of graphic material such as graphs, charts, globes, maps and pictures. Even though it is not done in any wide range, there are evident of their usage in schools.

Other schools had evolved with time to put to use recent technologies developments which can facilitate learning. Such schools possess, televisions, audio and video CD, computer iPods, internet etc.

Schools in Cameroon had been making efforts to evolve with the changing time. Another point of interest here that limits the possible use of some teaching and learning technologies in the teacher's ability to make use of them to achieve the intended learning outcome.

In Cameroon three major categories of schools are being operated; public, secondary and high school, technical, lay private secondary and mission (public, lay private and mission) schools. This provides a wider variety of ways in which recent educational reforms are being integrated into the school systems in Cameroon.

According to Tetang Tchinda Josué report of June 2007, he states that Cameroon is amongst the sub-Saharan African countries that are making enormous progress in the use of information and communication technology.

Private schools introduced ICT's into their curriculum in the 1990's. Yet up till present, there is no specific policy guiding teaching and/or the use of ICTs in education. This has led to each private school applying its own teaching method or programme. A majority of them are using computers for basic ICT literacy.

ICT was officially introduced into Cameroon education in 2001 by the president. The cyber educational project launched by the government targeted two sectors: secondary and tertiary education. Some of the achievements are: the establishments of multimedia resource centers (MRCs) in universities professional and technological schools, and some government secondary schools. The hyper realization of this project is the recent donation of laptops ( Paul Biya Higher Education Vision project) which saw all state and private university students receive a laptop from the head of state in Cameroon.

Even with this, it has been noted that government secondary schools have a low purchasing power and no budget has been allocated to support ICT- related activities in schools. Some mission and private schools have been involved in this project. Thus creating a gap between the two educational systems.

Still, most of the online learning resources accessible through the government secondary school platform CAMEDUC are in the French language, thus constituting a handicap for the English speaking community. Mbangwana
(2008), it also drafted national guideline for teaching ICT in secondary schools and primary schools.

According to Mbangwana (2008), Schools are responding timidly to the information age and the knowledge economy through the use of ICT, which today permit many aspects of urban life. ICT is used to perpetuate and reinforce the curriculum taught in the traditional way. ICT should be used as a set of tools that can be used for more in-depth and interactive teaching and learning.

The arrival of mobile phones has greatly altered information and communication landscape within Cameroon. Four companies are competing in the sector; MTN, ORANGE, NEXTEL and CAMTEL MOBILE. The Cameroonian government has also made considerable efforts to respond to the need for quality education and the demands of globalization. Amongst these could be cite the liberalization of the audio-visual media sector, the abolition of custom charges for imported communication equipment and the introduction of computers and internet facilities in schools and colleges.

Consequently, teachers have to develop the ability to demonstrate how these technologies can be used for academic purpose and convey the educational advantages of computers, internet, and cell phones. Audio/videotapes, interactive TV, digital radio and CD-ROMs to their students

The project for introducing ICT in schools was given an impetus by two presidential statement in 2001 which brought ICTs into the realm of education at all levels of schooling. This statement clearly stipulated that imported computers and their accessories were to be duty-free for schools.

In putting to effect the presidential statement and the World Bank initiative, MINEDUC authorized the inspectorate general of pedagogy in charge of teaching computer science at all levels to design and develop projects on cyber education in Cameroon. The project was implemented in April 2001.

In 2001, key strategies on using ICTs in education were highlighted. In the first official draft of Cameroon national information and communication infrastructure (NICI) policy and plan prepared by the government with support from the united nation Development Program (UNDP) and the United Nation Economic Commission for Africa (UNECA). In this document, the Cameroonian government recognized ICTs as a national priority along with education, health, forestry and governance.

As an indicator in the NICI plan document, the government has resolved to achieve the following;

1. Modernizing the educational system through the introduction of ICT in schools.

2. Introducing ICT application training modules into national universities.

3. Training teachers in the use of ICT.

4. Multiplying pedagogic resource centres for teachers and students.

5. Establish distance training facilities.

6. Providing support for the production of ICT teaching material (didactical) 


\section{Implementation}

$>$ External support form partners and the president of the republic, championed the moved toward the project implementation.

$>$ In 2002 the decision defining the conditions for the creation of MRCs in government secondary schools was published.

$>$ In 2003, the decree introducing ICTs in education was published by the ministry of National Education presently (MINESEC).

$>$ In 2004, the ministry created CAAP meaning cellule d'Appui àL'Action Pédagogique that is National Pedagogic Support Unit which is equip with a distance training unit called unite de Formation à Distance (UFAD) expected to ensure the training and capacitybuilding for teachers and distance learning.

\section{Infrastructure}

Private schools introduced ICT in their curricula in 1990, 1998 and 1999, even before the government decided to introduce them in 2001. Some of them are using high technology to connect to the internet either VSAT or special lines.

In 2000, there were no government secondary schools, and as of February 2007, only 17 of them or $2 \%$ have been equipped with MRCs. Currently, about 160,000 students are connected to about 10,000 computers Tenang (2007).

Private or mission schools are generally equipped with computer rooms. But the framework of the cyber education project, MRCs are being established in government secondary schools and are equipped with a local area connection (LAN), servers, word processing software and peripherals such as printers, scanners and CD-Roms. They may also have video projectors, videotape, televisions and internet connectivity some of which is through VSATs. The explosion of the social media in recent years has further increase the exploration of internet through cell phones using $3 \mathrm{G}$ or $4 \mathrm{G}$ networks. Millions of students can now easily access valuable academic information from online libraries worldwide. Even at this no policy has defined the use or application of technology for educational concern. There is generally no agreed from work for school to adapt technology to learning concern.

\section{Theoretical Framework}

Constructivist approaches to teaching and learning have emerged from the work of psychologist such as Jerome Bruner, Jean Piaget and Lev. Vygostsky. They are two major stands for constructivist perspective. These two stands are cognitive constructivism and social constructivism. They also share many common perspectives about learning and learners. Donadsen (1994) proposed that there are eight characteristics that differentiate constructivist learning environment.

1. Constructivist learning environment provide multiple representations of realities.

2. Multiple representations avoid over simplification and represent the complexity of the real world.

3. It emphasizes knowledge construction instead of knowledge reproduction.

4. It also emphasizes authentic tasks in a meaningful context rather than abstract instruction out of context.
5. Constructivist learning provides learning environment such as real-world settings or case-based leaning instead of predetermined sequence of instruction.

6. It encourages thoughtful reflection on experience.

7. It enables content and context dependent knowledge construction.

8. It supports collaborative construction of knowledge through social negotiations, not competition amongst learners of recognition.

Constructivist's central idea is that human learning is constructed that learners build new knowledge upon the foundation of previous learning. This view sharply contrasts with one in which learning is the passive transmission of information from one individual (teacher) to the other (student). Two notions orbits around the idea of constructivism. The first is that learners construct new understanding using what they already know and secondly that learners confront their understanding in light of what they encountered in the new learning situation.

Constructivism has important implications for teaching. Firstly, teaching cannot be viewed as the transmission of knowledge form the enlightened to the unenlightened. Constructivist teachers do not take the role of the "sage on the stage", rather teachers act as "guides on the side" who provides students with opportunities to test the adequacy of their current understandings. (Wesley A, Hoover (1996) states).

If new knowledge is actively built, then time is needed to build it. Simple, time facilitates student's reflection about new experiences how those experiences line up against current understandings and how a different understanding might provide students with an improved (not correct) view of the world. Instruction must be designed to provide opportunities for such construction.

Constructivism is a theory of knowledge (epistemology) which argues that, humans generate knowledge and meaning from their experiences. Constructivism is not a specific pedagogy, although it is often confused with constructionism, an educational theory developed by Seymour Papert, inspired by constructivist and experiential learning ideas of Jean Piaget.

Piaget's theory of constructivist learning has had wide ranging impact on learning theories and teaching methods in education and is an underlying theme of many educational reform movements.

Today, constructivist theories are influential throughout much of the informal learning sector. Formalization of the theory of constructivism is generally attributed to Jean Piaget who articulated mechanisms by which knowledge is internalized by learners. He suggested that through processes of accommodation and assimilation, individuals construct new knowledge from their experiences. When individuals assimilate, they incorporate the new experience into an already existing framework without changing that framework.

This may occur when individuals experience is aligned with their internal representations of the world but may also occur as a failure to change faulty understandings. For example, they may not notice events, may misunderstand 
input from others or may decide that an event is a fluke and it's therefore unimportant as information about the world.

In contrast Santrock (2004) claims that when individual experience contradict their internal representations, they may change their perception of the experiences to fit their internal representations. According to the theory, accommodation is the process of framing one's mental representation of the external world to fit new experiences.

Accommodation can be understood as the mechanism by which failure leads to learning: when we act on the expectation that the world operates in one way and it violates our expectations, we often fail but by accommodating this new experience and reframing our model of the way the world works we learn from the experience of failure or other's failure.

In both cases, the theory of constructivism suggests that learner's construct knowledge out of their experiences. However, constructivism is often associated with pedagogic approaches that promote active learning or learning by doing.

One social; constructivist notion is that of authentic or situated learning where students takes part in activities which are directly relevant to the application of learning and which take place within a culture similar to the applied setting Brown et Al. (1989).

In this view teacher' role of the assessor becomes one of entering into dialogue with the person being assessed to find out their current level of performance on any task and sharing with them possible ways in which that performance might be improved on a subsequent occasion.

Thus, assessment and learning are seen as inextricably linked and not separate processes Holt and Wallard-Holt (2000). According to this viewpoint, teachers should see assessment as a continuous and interactive process that measures the achievement of the learner, the quality of the learning experience and courseware. The feedback created by the assessment process serves as a direct foundation for further development.

The world, in which the learner needs to operate, does not approach one in the form of different subjects, but as a complex myriad of facts, problems, dimensions and perception Ackerman (1996).

Learners should constantly be challenged with tasks that refer to skills and knowledge just beyond their current level of mastery. This will capture their motivation and build on previous successes in order to enhance the confidence of the learner (Brownstein 2001). Vygotsky (1978) further claimed that instruction is good only when it proceeds ahead of development. Learners must not only have ownership of the learning or problem-solving process, but of the problem itself Derry (1999).

Most educational technologists do link education to technology (Garrison, 1987) and may view it as different from other forms of education. Claims about the effect of new technologies on learning have caused many people to suggest a change in the way6 new technologies are evaluated for learning (Clark, 1989).
Although Salomon (1981) and Clark (1991) make the point that instructional strategies and not the medium is the key to effective learning, technology and production considerations rather than teaching-learning theory or the instructional development process are often the driving forces behind educational programs.

Studies on the use of various media in education have supported Schramm's view that " learning seems to be affected more by what is delivered than by the delivery medium" (1977, p. 273) and Clark's analogy of media " not influencing learning any more than the truck that delivers groceries influences the nutrition of a community" (1983, p. 3).

Also, studies comparing education in the classroom with technologically-delivered classes (Beare, 1989; Mc Cleary and Egan, 1989) showed a significant difference in academic performance.

Recent developments in technology are believed to be removing some of the disadvantages associated with media in education. Bates (1984) suggest that new technologies promise " a wider range of teaching functions and a higher quality of learning, lower costs, greater students control, more interaction and feedback for students “ (p.223).

\section{Technological; Responsibilities for Teachers}

1. Teachers need to understand and support the importance of student learning to use information technology tools as an important component of their preparation for further education, work and life in general.

2. Teachers need to demonstrate support of technology use by developing skills, knowledge and strategies necessary to model effective uses of technology.

3. Teachers need to learn uses of technologies that provide assessment feedbacks to parents, students and other teachers about how well students are learning and then use that data to improve learning productivity.

4. Teachers need to instill into their students the social, ethical, legal and human issues surrounding the use of technology.

Moral values and ethical choices are tested and affected by technological change and new possibilities. Death and life, and the determination of both are subject to technological influence and modification. Technology shapes and is shaped by culture and values.

Technology cannot be separated from daily living. Technological resources are consumed, technological solutions are created and applied, and technological tools and products are routinely used. Yet people routinely misunderstand, misrepresent, and misuse technologies and technological products. Not everyone may think of technology but it may as well be if it is not understood (Di Sessa A.A 2000).

Modern scientific practice cannot be conducted without employing sophisticated technological tolls and processes. Each has effects which are felt in both social and personal contexts illustrate the practices of each and the relationships between them in their impact on humans (Trowbridge and Bybee, 1990). 


\section{METHODOLOGY}

The research designed for this paper was the survey research design. In this design, opinions of people in the sample representing the target population were collected using questionnaire and this was used to analyze the hypothesis.

\section{Population of the Study}

This study was carried out in government secondary schools of general education in the six divisions of the South West Region of Cameroon namely; Manyu, Fako, KupeMuanenguba, Lebialem, Ndian and Meme divisions. The study was carried out in schools having the second cycles. These schools are located both in the urban and rural areas. Population according to Luma, Ngoh and Mbangwana (1999) is a portion of the universe to which the researcher has access but generally, population is the total number of items, objects and persons to which findings will be applied.
Thus, the target population of this study included all the teachers and students of public secondary and high school in the South West Region of Cameroon. The number of teachers stands at about 1936 teachers and 43212 students.

Table 1: Population of the Study

\begin{tabular}{|c|c|c|c|c|}
\hline S/N & Division & $\begin{array}{c}\text { No of } \\
\text { schools }\end{array}$ & Students & Teachers \\
\hline $\mathbf{1}$ & Fako & 18 & 13146 & 573 \\
\hline $\mathbf{2}$ & Meme & 13 & 10274 & 475 \\
\hline $\mathbf{3}$ & $\begin{array}{c}\text { Kupe } \\
\text { Muanenguba }\end{array}$ & 12 & 6928 & 241 \\
\hline $\mathbf{4}$ & Manyu & 14 & 7644 & 264 \\
\hline $\mathbf{5}$ & Ndian & 09 & 2477 & 199 \\
\hline $\mathbf{6}$ & Lebialem & 09 & 2734 & 202 \\
\hline Total & & 75 & 43212 & 1936 \\
\hline
\end{tabular}

Source: South West Regional statistical Report (20042006) p.137b

\section{Sample of Population}

Table 2: Summary of Sample selected per school and per division

\begin{tabular}{|l|c|c|c|c|}
\hline \multicolumn{1}{|c|}{ Name of School } & Accessible Population & \multicolumn{2}{c|}{ Sample } \\
\hline Fako Division & Teachers & Students & Teacher & Student \\
\hline GHS Buea & 87 & 2195 & 9 & 39 \\
\hline GBHS Muyuka & 64 & 1781 & 7 & 31 \\
\hline GBHS Muea & 51 & 680 & 8 & 12 \\
\hline Meme Division & & & & \\
\hline Ccas Kumba & 104 & 2350 & 11 & 42 \\
\hline GHS Kake & 33 & 604 & 4 & 9 \\
\hline GBHS Kumba & 118 & 2274 & 12 & 40 \\
\hline Ndian Division & & & & \\
\hline GBHS Mundemba & 34 & 813 & 4 & 15 \\
\hline GHS EkondoTiti & 42 & 786 & 4 & 14 \\
\hline Manyu Division & & & & \\
\hline GHS Mamfe & 58 & 1131 & 6 & 20 \\
\hline GBHS Mamfe & 43 & 718 & 4 & 13 \\
\hline GHS Kembong & 31 & 702 & 6 & 13 \\
\hline GHS Ossing & 27 & 615 & 3 & 12 \\
\hline Kupe Muanenguba & & & & \\
\hline GBHS Tombel & 67 & 1282 & 7 & 22 \\
\hline GHS Nguti & 31 & 561 & 5 & 11 \\
\hline GSS Manyenmen & 27 & 793 & 3 & 14 \\
\hline Lebialem Division & & & & \\
\hline GBHS Menji & 38 & 686 & 4 & 12 \\
\hline GSS Alou & 24 & 614 & 3 & 11 \\
\hline Total & 937 & 18443 & 100 & 330 \\
\hline
\end{tabular}

A sample is a specific number of items, objects or persons drawn from a target population through the sampling process. Amin (2005), defines a sample as a collection of some (a subset) elements of the population. In that same view, Fraenked (2001) defines a sample as a "group on which information is obtained".

A sample is a portion of the population whose results can be generalized to the entire population. Sampling therefore is a process of extracting a portion of the population from which generalizations of the population can be made.

\section{Sampling Technique}

The sample was selected using simple random sampling techniques and the proportionate stratified sampling technique. The simple random technique was used in selecting the schools in each division. Here the researcher visited each division and wrote down the name of the schools in the division on a piece of paper.

The pieces of paper were folded and put in a basket where they were shuffled. The researcher blindly picked a folded piece of paper, unfolded and wrote down the name of the school. The unfolded paper was refolded and put in the basket. It was reshuffled for further picking, unfolding and recording. The process continued until the sample require from each division was gotten. 
The proportionate stratified random sampling technique was use to select the number of teachers and students for each school. The sample for each school was proportionate to the accessible population of that school. A section of the population was taken to represent the population.

Consequently, the six (6) divisions of the southwest Region made up seventeen school sand some 100 teachers and 330 students of these schools constituted the sample of the study.

\section{Instruments of Data Collection}

The research instrument used for this study is the questionnaire and interviews. The questionnaire was constructed in conformity with the variables under study. The role of educational technology in the teaching and learning process.

The items constructed were based on the close questions study and there were thirty statements to be rated on each variable as; strongly agree, agreed, disagree, strongly disagree and undecided by respondents.

A cover letter was directed to respondents who completed the questionnaire. The letter stated categorically, that confidentiality would be respected and that responses were to be used solely for the purpose of research.

The research warrantees, two questionnaires directed toward students to evaluate the role of educational technology in learning and another toward teachers, to collect data which will be analyzed to find out the role of educational technology in the teaching process. Each of the questionnaires had four sections;

\section{Administration of Instruments}

The schools in the accessible population were visited, and the principals of the schools contacted. The name of the teachers present and classes of the student involved in the sample were requested for, and in some cases the principal took the researcher around the school and observe the researcher administer the questionnaires to both the teachers and to the students. In other cases the principal's delegates the vice principal for the same purpose. For the interviews, the principals and their vice were interviewed in their offices.

\section{Return Rate of Questionnaire}

\begin{tabular}{|c|c|c|c|c|}
\hline Name of School & \multicolumn{2}{|c|}{ No of Questionnaires administered } & \multicolumn{2}{|c|}{ Return Rate } \\
\hline Fako Division & Teachers & Students & Teachers & Students \\
\hline GHS Buea & 9 & 39 & 9 & 39 \\
\hline GBHS Muyuka & re & 31 & 7 & 31 \\
\hline GBHS Muea & 8 trend & 1 SGIE 12 & 8 & 12 \\
\hline Meme Division & Reser & rch and & 28 & \\
\hline Ccas Kumba & 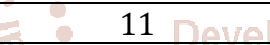 & 42 & 11 & 42 \\
\hline GHS Kake & 8 & 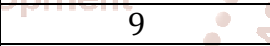 & 4 & 9 \\
\hline GBHS Kumba & $0.12 \mathrm{SSN}: 2$ & $56-64714$ & 12 & 14 \\
\hline Ndian Division & 8 & 0.0 & & \\
\hline GBHS Mundemba & 4 & 15 & 4 & 15 \\
\hline GHS EkondoTiti & $4+1$ & $\begin{array}{r}14 \\
\end{array}$ & 4 & 14 \\
\hline Manyu Division & 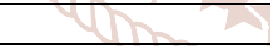 & $S$ & & \\
\hline GHS Mamfe & 6 & $\begin{array}{r}20 \\
\end{array}$ & 6 & 20 \\
\hline GBHS Mamfe & 4 & 13 & 4 & 13 \\
\hline GHS Kembong & 6 & 13 & 6 & 13 \\
\hline GHS Ossing & 3 & 12 & 3 & 12 \\
\hline Kupe Muanenguba & & & & \\
\hline GBHS Tombel & 7 & 13 & 7 & 13 \\
\hline GHS Nguti & 5 & 11 & 5 & 11 \\
\hline GSS Manyenmen & 3 & 14 & 3 & 14 \\
\hline Lebialem Division & & & & \\
\hline GBHS Menji & 4 & 12 & 4 & 12 \\
\hline GSS Alou & 3 & 11 & 3 & 11 \\
\hline Total & 100 & 330 & 100 & 330 \\
\hline
\end{tabular}

\section{Statistical Method for Data Analysis}

Both descriptive and inferential statistics were used to analyze and verify the hypothesis. For the descriptive statistics, percentages were used to evaluate and describe the responses registered on the questionnaire, while for inferential statistics , the Chi Square Test of independence was used to verify the hypothesis.

The formula for percentages (\%) is given by

$$
\%=\frac{\text { Number of Furabutur repondene }}{\text { Sample Size }} \times 100
$$

The Chi Square $\left(\mathrm{X}^{2}\right)$ formula is given by ;

$$
x^{2}=\sum \frac{(f o-f \theta)^{2}}{f \theta}
$$


If there is no relationship between the two variables we would expect the same number of respondent to respond to each category on the scale. Mbua (2003). That is

If the number of Scales $=3$

The $\mathrm{f}_{\mathrm{e}=\mathrm{N}} / \mathrm{3}$

Where,

$\mathrm{N}=$ Sample Size

Decision rule: where $x^{2}$ calculated value is greater than $x^{2}$ critical value, the Null hypothesis is rejected while the alternative is retained. Where $x^{2}$ calculated is less than the Value of $x^{2}$ critical value, the null hypothesis is retained while the alternative is rejected.

The magnitude of relationship is determined by comparing the contingency coefficient value (C.C) to the contingency maximum value (Cmax).

These are gotten by

$$
\mathrm{CC}=\sqrt{\frac{x^{2}}{x^{2}+N I}}
$$$$
\operatorname{Cmax}=\sqrt{\frac{K-I}{K}}
$$

Where,

$\mathrm{X}^{2}=$ Chi Square calculated value

$\mathrm{N}=$ Sample Size

K-Smaller number of rows or columns

\section{Magnitude of Relationship}

\section{FINDINGS AND DISCUSSIONS}

The table below presents the opinion statements of the respondents

\begin{tabular}{|c|c|c|c|c|c|c|c|}
\hline \multirow{2}{*}{$\mathbf{S} / \mathbf{N}$} & \multirow{2}{*}{ Items } & \multicolumn{6}{|c|}{ Responses Option } \\
\hline & & SA & A & D & SD & UD & $\mathbf{N}$ \\
\hline 1 & Television, radio and internet are sources of content for my lessons. & 40 & 30 & 11 & 10 & 9 & 100 \\
\hline 2 & Audio and Video CDs cab stimulate class Discussion. & 42 & 33 & 7 & 12 & 6 & 100 \\
\hline 3 & Experimental and laboratory lessons provide learners with practical experiences. & 52 & 34 & 10 & 2 & 2 & 100 \\
\hline 4 & Lesson content dictates my choice of didactic material. & 40 & 40 & 13 & 5 & 2 & 100 \\
\hline 5 & Text books, prints, audio visual make lesson more explicit. & 45 & 35 & 10 & 2 & 8 & 100 \\
\hline
\end{tabular}

\section{A summary of the opinion statements of the respondents}

\begin{tabular}{|c|c|c|c|}
\hline & Responses & Frequencies & Percentages \\
\hline Agree & 391 & 391 & $75.2 \%$ \\
\hline Disagree & 81 & 81 & $16.2 \%$ \\
\hline Undecided & 27 & 27 & $5.6 \%$ \\
\hline Total & 500 & 500 & $100 \%$ \\
\hline
\end{tabular}

The table above and the preceding pie chart show that $75.2 \%$ of teachers who reacted agreed to the research question items. While $16.2 \%$ disagreed and $5.6 \%$ were neutral or undecided.

Sales

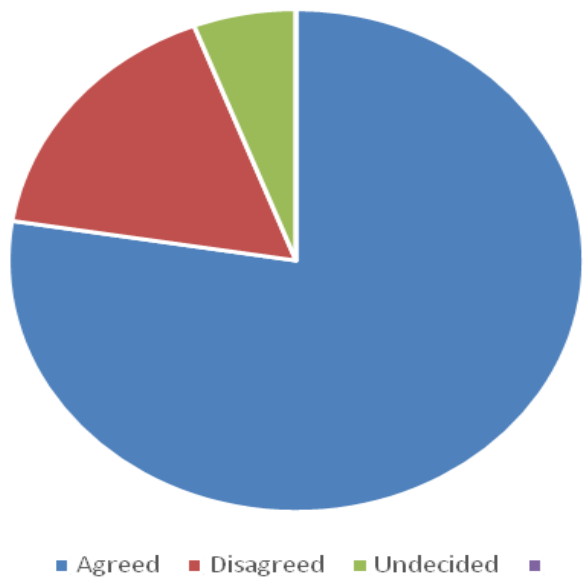

Figure Pie chart describing Research Question 


\section{Findings from Hypothesis}

$\mathbf{H}_{0}$ : There is no relationship between educational technology and the quality teaching.

$\mathbf{H}_{\mathbf{a}}$ : There is a relationship between the educational technology and quality teaching.

\section{Calculation of $\mathrm{x} 2$ of the Null $\left(\mathrm{H}_{0} 5\right)$ hypothesis}

\begin{tabular}{|c|c|c|c|c|c|}
\hline & Observed & Expected & Fo-fe & $(\mathrm{fo}-\mathrm{fe})^{2}$ & (fo-fe) $^{2 / f e}$ \\
\hline Agree & 78 & 23.3 & 54.7 & 2992.1 & 54.7 \\
\hline Neutral & 6 & 23.3 & -16.7 & -278.9 & -16.7 \\
\hline Disagree & 16 & 23.3 & -6.9 & -47.6 & -6.9 \\
\hline \multicolumn{5}{c}{$\Sigma \frac{(f o-f e)^{2}}{f o}$} & 31.1 \\
\hline
\end{tabular}

$\mathrm{Df}=$ number of classes - number of restriction

Number of classes $=3$

Number of Restriction $=1$

$\mathrm{V}=\quad 3-1$

$\mathrm{df}=2$

a-Level of significance $=0.05$

Calculated $\mathrm{x}^{2} \quad=31.1$

Critical $\mathrm{x}^{2} \quad=5.99$

\section{Decision Rule}

The chi-square cal (31.1) is greater than chi-square critical (5.991) with this inference, we reject the null hypothesis and retain the alternative. Thus, there is a relationship between educational technology quality teachings.

The magnitude of the relationship is determined by comparing the contingency coefficient value (CC) to the contingency maximum value ( $\mathrm{C}$ max).

$$
\begin{aligned}
& C C=\sqrt{\frac{31.1}{100+243}} \\
& \sqrt{\frac{31.1}{1243}}
\end{aligned}
$$

Since 0.5 lies between $0.4-0.81$, the magnitude is high. This therefore is an indication that, there is a high relationship between educational technology and quality teaching.

Null hypothesis states that they is no relationship between educational; media and quality teaching. The findings show that the null hypothesis is rejected at 24.3 Chi-Square calculated value and 5.991 Chi-square critical values. Thus the alternative hypothesis which states that there is a relationship between educational media and teaching.

Reiser (1987) echoes Thomas Edison proclamation that, due quality to the intervention of films "our school system will be completely changed". Wright (1991) makes it clear that success of audio-visual generated a new interest is its usage in class.

Wright (1991) in a survey to measure television as an educational tool, Wright states that television is not an educational method but an instrument for transmitting instruction. According to Verduin and Clark (1991), information must flow in such a manner that all involved are aware of common goals, activities and procedures. This to him is not possible without proper medium of communication.
The interest to use educational technologies to accomplish a variety of educational delivery need has grown to a point where preparing teachers to use technologies is assumed to be the main function and primary interest of educational technologist.

Bates (1984) suggest that the new technology promise a wider range of teaching functions and a higher quality of learning lower costs, greater students control, more interaction and feedback for students.

Is there a relationship between educational technology and quality teaching? To this question, $75.2 \%$ agreed while $16.2 \%$ disagreed. The Chi-square calculated is 31.1 greater than Chi-square critical 5.991 thus retaining the alternative hypothesis with a High magnitude of relationship.

The practical conclusions arrived at from the analysis of the study showed that;

$>$ Students as well as teachers are so conscious of the evolutionary framework of the times. The students acknowledged the fast changing influence of the traditional classroom setup as opposed to the incoming technologically oriented classroom. It was found out that students explore other mediums in a bid to acquire knowledge.'

It was also found out that students are making considerable efforts to acquire skills in new information and communication technologies. Students go extra miles to use radio, television, internet through cyber café to know what is happening in the external world. The research found out that they is a slim difference between urban and rural students as long as information technology is concerned.

$>$ The research found that all forms of technology are used in class for the attainment of intended learning outcome. Technology can serve as a resource to help develop higher other thinking, creativity and research skill.

$>$ It has also been realized through this research that, the interest to use educational technologies to accomplish a variety of educational delivery need, has grown to a point where preparing teachers to use technology is assumed to be the main function and primary interest of educational technologists. It also found out that teachers in Cameroonian schools are not trained to use technology as a teaching resource but are doing so through refresher courses and workshops.

$>$ Very qualified teachers will provide a more intensive use of educational technological gadgets in the teaching and learning process than less qualified teachers. 
International Journal of Trend in Scientific Research and Development (IJTSRD) @ www.ijtsrd.com eISSN: 2456-6470

\section{REFERENCES}

[1] Adeya, C (2001). Information and Communication Technology in Africa. A selected review of projects and studies. United kingdoms. International network for the Availaibility of Scientific publications (INSAP).

[2] AMIN, E.M (2005). Social Science Research: Conception Methodology and Analysis. Kampala, Uganda. Makere University printers.

[3] Aminpour, F. (2007). E-learning in universities and higher education Ketab-iron.

[4] Ammari, A.C, Slama, J. (2006). The development of a remote laboratory for internet-based engineering education. Journal for Asychronous Learning Network from:http://www.sloanc.org/publications/vion4 ammari-member.asp.

[5] Anderson-inman, L and Reinking, D (1998), Learning form text in technological socirty. USA, NJ: Lawrence Erlbaum Inc.

[6] Becker, H. J and Ravit, J (1997, August). The Equity head of Promising -Innovations: Chicago USA. Richbold publishing.

[7] Becker, H.J (2002). Who is wired and who's not children access to the use of computer technology. USA. Basic Bocks

[8] Benton Foundation (2002). Great expectation in educational Technology. Wasghington DC. U.S.A Benton Foundation.

[9] Bostock, S.J (1996). A critical Review of Laurillard's Classification of Educational Media Instruction Science. Chicago, Rand McNally Collage Publishing Company.

[10] Bowe F.G (2000). Universal Design in Education Bergen and Garvey Westport, CT.

[11] Brunel.J (1956). The process of education. New York Usa: Vinateg Books LIMITED.

[12] Brunner, C, Fasca, C. Heinze, J Honey, M.Light, D. Mandinach, E \& Wexler, D. (2005). Linking data and learning. The Grow Network Study. Journal of Education for students Placed at Risk 10(3), 241-267.

[13] Byron, E, Bingham, M (2001). Factors influencing the effective use of technology for teaching. New York U.S.A Education center for children and technology.

[14] Campell, J.o, Bourne, J.R Mosternam, P. J Nahvi, M.Rassai, R. Brodersen A.J Et Al (2004). Cost effective distributive learning with electronics labs. New York. Random House.

[15] Col (2005). A new publication of the commonwealth of learning. Connections Col, Vancouver, Canada February 2005/Vol.1, Number 1 PP1-16.

[16] Cradler, J McNabb, M, Freeman M, Burchett, R (May 2002). " How does technology influence student learning?". Learning and teaching with technology.

[17] Cradler, John and Bridgforth, Elizerbert (1996). The role of Online Comminication in Schools http:fwl.org/techpolicy.

[18] Cuban, Larry. (August 22, 1999). “Don't Blame Teachers for how Computer are used in the classrooms" Los Angeles Time.

http.www.uslosamblestime/today.

[19] Culp, K., Honey, M and Mandinah E. (2003). A retrospect of twenty years of educational technology policy Washington DC USA. Departments of Education.

[20] Culp, K. Honey, M and Mandinah E. (2003). A retrospective on twenty years of education technology policy. Washington, DC: US Department of Education.

[21] Available at: http://www.nationaledtechplan.org/participate/20yea rs.pdf

[22] David, J. (1996). Pedagogy: Learning Styles. New York . McGraw-Hill COMPANY.

[23] Dickey M. (2003) 3d Virtual world. An emerging technology for traditional and distance learning proceedings.

[24] Dirr, P (2004). Measuring the Impact of technology on classroom teaching and learning. Alexandria, VA http:www/the-atcc.org/docDownload.asp

[25] Earle et al (2002). Learning with Technological Help. USA McGraw Hill

[26] Elton, Lewis(1999). New ways of Learning in Higher Education. N.Y. U.S.A Basic Books.

[27] eMINTS National Centre. (2005,September 15). Fact Sheet.

[28] Columbia, MO: Author

[29] Available: http://www.emints.org/about/emintsfactsheet.pdf

[30] eSchool News. (2005b, September). Mich.laptop program shows early success. Staff and wire service reports. P.15

[31] eSchool News. (2005b, September). Study: web use nearly ubiquitous for today's teens. Staff and wire service reports. P 17.

[32] ETS: International ICT Literacy Panel (2001). Digital transformation: a framework for ICT literacy. Educational Testing Service: http://www.ets.org/reaserch/ictliteracy/index.html.

[33] Farrant (1980). Learning for a better Tomorrow. Great Britain Oxford University Press.

[34] Gamoran, Secada\&Mariett (1998). Teaching with Technology Richrat Gr.

[35] Gardner, H (1983). Crames and Minds: Theories of multiple intelligence. New York: Basic Books.

[36] Gee, D.G (1990). The impact of Students' Prefered Learning Styles variable in a distance education. U.S.A New Mexico University Press.

[37] Hijazi. S, Bernard, P Plaisent, M and Maguirage, L (2003). Interactive technology impaction quality education. http:www.ejel.org/volume-i-issue.art 5 hajazi.

[38] Holt and Willaard- Holt. Science and Technology. Oxford University Press. GB 
[39] Hruska-Riechmann, S and G .Rasha, A.F (1982). Students learning Styles and Brain Behaviour. Berlin. Gr. Blemierictag.

[40] http://www.nationaledtechplan.org/participate/20yea rs.pdf.

[41] http://www.oln.org/conference/OLV2003/papers/Dic keys3D

[42] KAY, k AND Honey, M. Beyond technology Competence; A vision of ICT literacy to prepare students for the $21^{\text {st }}$ century Charleston, W.V USA .Evantia.

[43] Kemp J. Morrison, G. and Ross, S.M (1998) Designing Effective instruction (2nded.) USA NJ. Book Limited

[44] Lightfoot, J. (2009). A comparative analysis of e-mail and face-face communication in an educational environments.

[45] Mac0jong (2008). Historical and Philosophical Foundation of Education. Cameroon. Limbe . Design House

[46] Marshall, J.m (2002). Learning with technology: evidence that technology can and does support learning. San Diego,CA

[47] Mbua (2002). Educational Admionistration, Theory and Practice. Cameroon Limbe. Design House

[48] Mosston, Mand Ashworth, S (1990). The spectrum of teaching styles. From command to discovery, Ny/060/USA Longman.

[49] Ndongko, T. and Tambo, L (2002). Education Development in Cameroon 1961-1999: issue and perspectives Nkemnji Global Tech.

[50] Nsamenang A. (2004). The teaching learning trasactrion: an Africatric Approach to Educational psychology. HDORS Vol.2. Cameroon. Bamenda. Anoh's printing Service.

[51] Reeve, T. (1998). The Impact of MEDIA AND Technology in School: San Francisco Mested USA.
[52] Sadker, M. and Sadker, D. (2000). Teachers, school and society ( $5^{\text {th }}$ ed.) New York. USA.McGraw-Hill.

[53] Samtrock, L. (1998). Adolescenses, New York. USA. McGraw -Hill

[54] Sarasin, L. (1998). Learningb Style Perspectives: Impact in the Classroom, G.B .Nova Southenstem University Press.

[55] Sherry L. and Jesse, D (2000). The Impact of TYechnology in Student Achievement. Derwer, co.uk.

[56] Somekh, B and Wiki, D. (1997). Using information technology effectively in teaching and learning. London. Routledge II New fetter Lane.

[57] Tambo I. (2003). Principles and methods of teaching. Cameroon. Limbe Anucam

[58] Tanjong, E (2006). Africa in international communication. Cameroon . Limbe. Design House.

[59] Tchombe, T.M (2004). Pshychological Parameters in Teaching Presses UniversitairesD’Afrrique.

[60] The Convergence of learning and Technology.

[61] Toffler A. \& Toffler H.(2006). Tomorrow's classroom. Moscow. New Print Link.

[62] Wartsch (1997). Helping them learn better.

[63] Wenger, Etienne (1999). Communities of Practice: Learning, meaning AND Identity (Boston, Cambridge University Press)

[64] Wenglimsky, H (1998). The relationship between educational technology and Student achievement.USA Prinseton, NJ

[65] Westley (1988). Impacting education NJ Book limited.

[66] Zinsi C. (2007). Corruption of Information Science Journal of the American Society For Information science and technology 58 (3) 335-350. 